\title{
Plasma arginine vasopressin in hyponatraemic patients receiving diuretics
}

\author{
R.R. Ghose \\ Singleton Hospital, Sketty, Swansea SA28QA, UK.
}

\begin{abstract}
Summary: Random estimations of plasma arginine vasopressin concentration were undertaken in 6 non-oedematous patients receiving diuretic therapy for hypertension, who were admitted to hospital with severe hyponatraemia. Hyponatraemia resolved within 2 weeks of discontinuing the diuretic. Measurable amounts of plasma arginine vasopressin were detected in all 6 patients.

Sequential biochemical measurements in one patient, performed when plasma sodium concentration and osmolality were returning to the normal range, disclosed that urine osmolality remained higher than plasma osmolality during the first 5 days, when urine volume and sodium excretion were low. Thus the rise in plasma sodium was not initially related to water diuresis. The ability to excrete a water load was severely limited on the fifth day, but improved progressively by the tenth and seventeenth days.

Diuretic-induced hyponatraemia is associated with incomplete suppression of anti-diuretic hormone secretion arising from non-osmotic stimulation, in conjunction with transient impairment of renal diluting ability which could be due to net sodium deficit.
\end{abstract}

\section{Introduction}

The patho-physiology of diuretic-induced hyponatraemia is not fully clarified. Hyponatraemia cannot be attributed to a direct effect of the diuretic on the renal tubule, but to renal and extra-renal effects accompanying diuretic administration, which are subsequently maintained by a receptor system sensitive to small changes in extracellular fluid volume. The effector site of this system is renal, related to antidiuretic hormone (ADH) activity and associated water conservation, which occurs in the presence of significant serum hypotonicity (Fuisz et al., 1962). Successful treatment of diuretic-induced hyponatraemia can be achieved by appropriate replacement of sodium ions, which can apparently over-ride these physiological adaptations (Roberts et al., 1977). Elevated levels of bio-assayable ADH have been demonstrated in diuretic-induced hyponatraemia (Fichman et al., 1971). Radio-immunoassay measurements of plasma arginine vasopressin (AVP) are reported in a small group of patients presenting with diuretic-induced hyponatraemia.

\section{Methods}

Plasma and urine electrolyte concentrations were measured by routine laboratory techniques, and

Correspondence: R.R. Ghose, F.R.C.P.

Accepted: 31 July 1985 osmolality by Fiske osmometer measuring freezing point depression. Body weight in Case 1 was measured using an Avery bed-weighing machine. Blood for AVP measurement was placed in a chilled vacutainer tube containing potassium EDTA, and plasma was separated using a refrigerated centrifuge. Plasma samples were flash-frozen with dry ice and acetone and transported by road to the Cobbold Laboratories, Middlesex Hospital, London. AVP was measured by a sensitive and specific radio-immunoassay (Stromberg et al., 1981). The assay has a detection limit of $0.1 \mathrm{pg} /$ $\mathrm{ml}$ (Dr J.D.H. Slater, personal communication).

A standard water load of $20 \mathrm{ml} / \mathrm{kg}$ body weight was given to patients 1 and 3 over a 30 minute period. Hourly urine collections were made for 4 hours thereafter, volume and osmolality being measured on each sample. The highest urine volume recorded in these collections is shown as $\mathrm{V}^{\max }(\mathrm{ml} / \mathrm{min})$, and the lowest urine osmolality in the same collection period as $\mathrm{Uosm}^{\text {min }}(\mathrm{mOsm} / \mathrm{kg})$.

\section{Patients and results}

The patients studied were emergency admissions to a general medical ward, where biochemical screening revealed a plasma sodium concentration below $125 \mathrm{mmol} / 1$. Plasma potassium concentration, initially and during recovery, exceeded $3.4 \mathrm{mmol} / 1$. All the patients were receiving diuretic therapy daily for

(C) The Fellowship of Postgraduate Medicine, 1985 
hypertension; but patients 3 and 4 were also diabetic, whilst patient 6 was an epileptic and required additional treatment. The diuretic was discontinued at the time of admission, but treatment for diabetes and epilepsy was continued unchanged. Clinical examination showed no evidence of volume depletion, such as postural hypotension, tachycardia or loss of skin tissue turgor. None of the patients were oedematous and none could remember whether thirst had been experienced before admission. Plasma sodium concentration returned to normal within 2 weeks of hospitalization and discontinuation of the diuretic.

\section{Case 1}

An 80 year old woman had been treated for hypertension over 2 years with hydrochlorothiazide $50 \mathrm{mg}$ and amiloride $5 \mathrm{mg}$ (as Moduretic) daily. She was admitted to hospital with mental confusion of 5 days duration.

Figure 1 shows a gradual rise in plasma sodium concentration $(\mathrm{PNa})$ and osmolality (Posm) over 2 weeks, which occurred with little change in the body weight. She regained clarity of mind after 2 days. Figure 2 shows serial water load tests performed on days 5,10 and 17 respectively. Plasma AVP was $0.8 \mathrm{pg} /$ $\mathrm{ml}$ on day 1 .

\section{Case 2}

A 64 year old man with moderate hypertension was treated with atenolol $100 \mathrm{mg}$ and bendrofluazide $5 \mathrm{mg}$ (as Tenoretic), once daily. Two months later he was admitted to hospital with weakness. Plasma sodium concentration was $99 \mathrm{mmol} / \mathrm{l}$, and potassium 3.4 $\mathrm{mmol} / \mathrm{l}$. On day 3 plasma AVP was $0.3 \mathrm{pg} / \mathrm{ml}$ when plasma sodium concentration was $116 \mathrm{mmol} / \mathrm{l}$, osmolality $241 \mathrm{mOsm} / \mathrm{kg}$, and potassium $3.6 \mathrm{mmol} / \mathrm{l}$. The urine osmolality was $616 \mathrm{mOsm} / \mathrm{kg}$ and volume $750 \mathrm{ml} / 24 \mathrm{~h}$.

Within 16 days he was again hypertensive with normal plasma sodium and potassium.

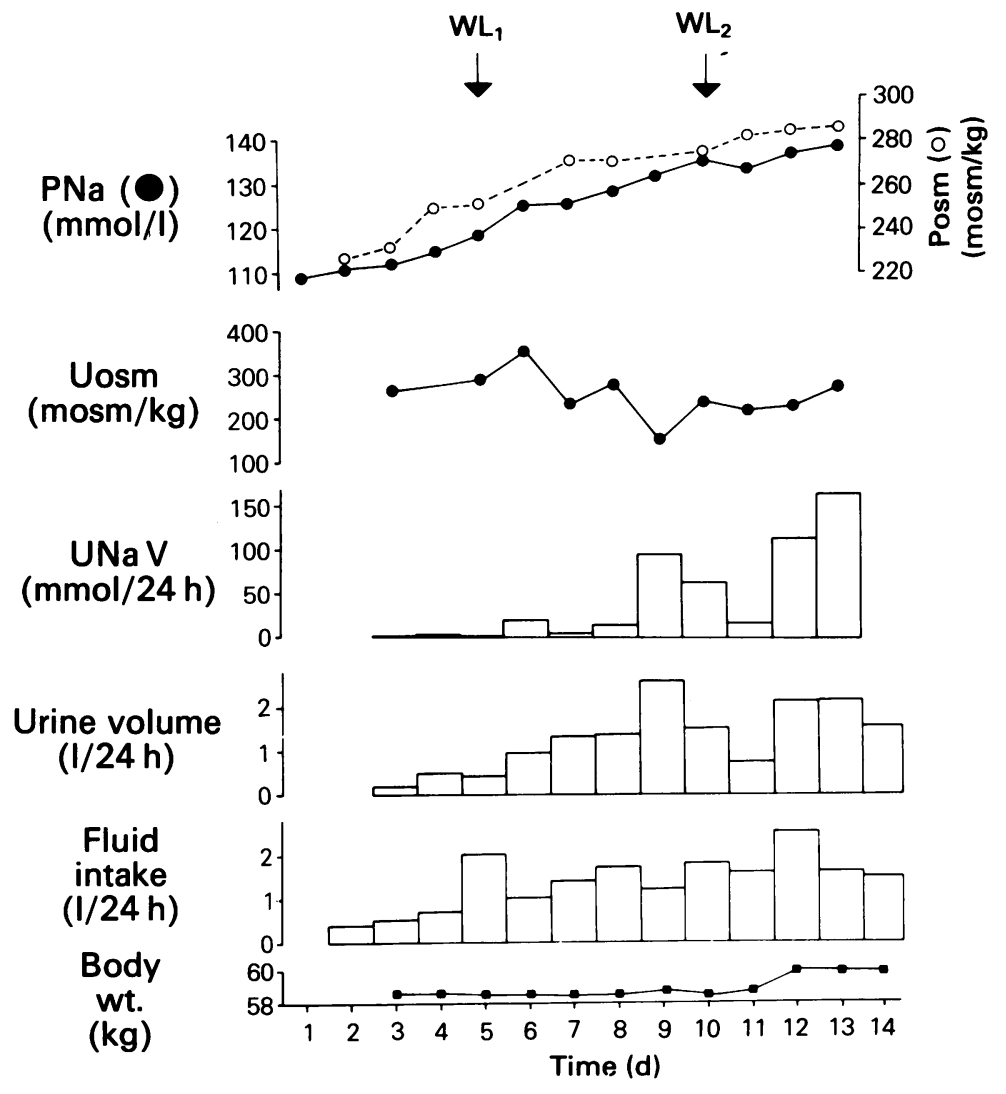

Figure 1 Case 1 shows gradual recovery of plasma sodium (PNa, $\bigcirc$ ) and osmolality (Posm, $\bigcirc)$ over 14 days with concurrent changes in urine osmolality, sodium excretion, urine volume and body weight. WL $=$ water load. 

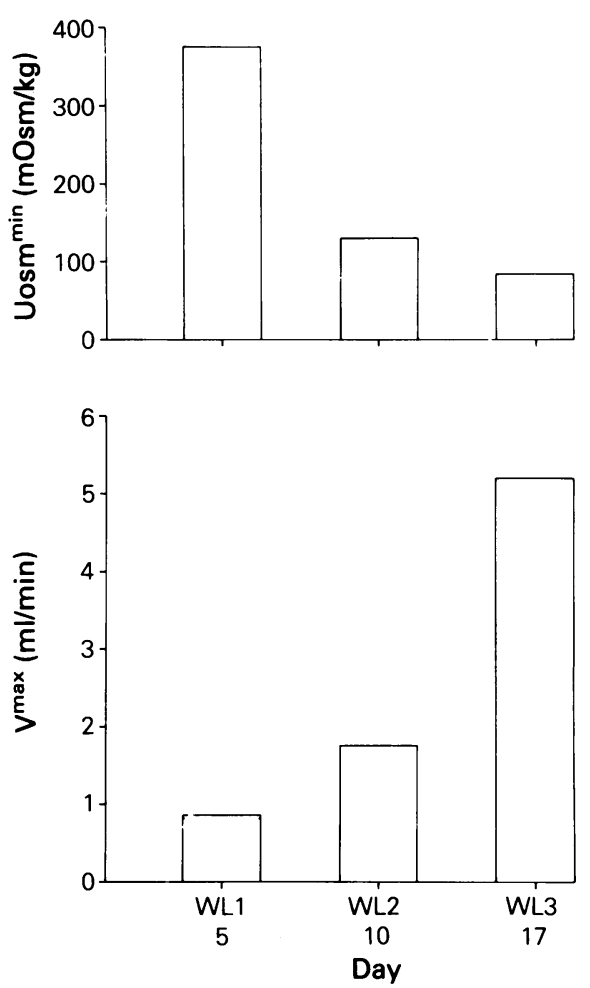

Figure 2 Water load (WL) tests were performed, on days 5,10 and 17 respectively in Case 1 , which reveal sequential changes in minimal urine osmolality $\left(\right.$ Uosm $^{\mathrm{min}}$ ) and maximal urine volume $\left(\mathrm{V}^{\max }\right)$.

\section{Case 3}

A 73 year old man was admitted to hospital in an acute confusional state. He was a longstanding diabetic receiving chlorpropamide $400 \mathrm{mg} / \mathrm{d}$. Concomitant hypertension was treated with hydrochlorothiazide $50 \mathrm{mg}$ and amiloride $5 \mathrm{mg}$ daily (as Moduretic). Blood glucose concentration was $16 \mathrm{mmol} / \mathrm{l}$, plasma sodium $120 \mathrm{mmol} / 1$, potassium $4.7 \mathrm{mmol} / 1$, urea $8.4 \mathrm{mmol} / 1$.

On day 3 plasma AVP was $0.3 \mathrm{pg} / \mathrm{ml}$, osmolality $268 \mathrm{mOsm} / \mathrm{kg}$, sodium $132 \mathrm{mmol} / \mathrm{l}$, and potassium $4.2 \mathrm{mmol} / \mathrm{l}$. The urine osmolality was $262 \mathrm{mOsm} / \mathrm{kg}$.

A water load on day 5 showed $\mathrm{V}^{\max } 1 \mathrm{ml} / \mathrm{min}$ and Uosm $^{\text {min }} 471 \mathrm{mOsm} / \mathrm{kg}$.

\section{Case 4}

A 71 year old woman with hypertension of 6 months' duration was treated with oxprenolol $80 \mathrm{mg}$ thrice daily and bendrofluazide $5 \mathrm{mg} / \mathrm{d}$. She had diabetes mellitus controlled for $5 \mathrm{y}$ on chlorpropamide $100 \mathrm{mg} / \mathrm{d}$. Hyponatraemia was detected on biochemical screening.
Plasma sodium $124 \mathrm{mmol} / 1$, osmolality $263 \mathrm{mOsm} / \mathrm{kg}$, potassium $4.9 \mathrm{mmol} / \mathrm{l}$, and AVP $1.1 \mathrm{pg} / \mathrm{ml}$. The urine osmolality was $643 \mathrm{mOsm} / \mathrm{kg}$.

Seven days after admission the plasma electrolytes were normal and the blood pressure unchanged. On weight reduction the patient required no drug treatment.

\section{Case 5}

A 61 year old man had been treated for hypertension over many years with oxprenolol and hydrochlorothiazide. He was admitted to hospital with acute myocardial infarction and the plasma sodium concentration was found to be $132 \mathrm{mmol} / \mathrm{l}$, and potassium $4.4 \mathrm{mmol} / 1$. On day 2 a single intravenous dose of frusemide $50 \mathrm{mg}$ was given, and by day 3 plasma sodium was $122 \mathrm{mmol} / \mathrm{l}$, potassium $4.5 \mathrm{mmol} / \mathrm{l}$, osmolality $254 \mathrm{mOsm} / \mathrm{kg}$, and AVP was $0.4 \mathrm{pg} / \mathrm{ml}$. The urine osmolality was $300 \mathrm{mOsm} / \mathrm{kg}$.

On day 10 when plasma sodium was $133 \mathrm{mmol} / \mathrm{l} \mathrm{a}$ water load showed $\mathrm{V}^{\max } 5.5 \mathrm{ml} / \mathrm{min}$, and Uosm ${ }^{\min }$ $151 \mathrm{mOsm} / \mathrm{kg}$.

\section{Case 6}

A 62 year old man was admitted having collapsed unconscious in the street. He was epileptic and received sodium phenytoin $100 \mathrm{mg}$ thrice daily. He also received bendrofluazide $5 \mathrm{mg} / \mathrm{d}$ for hypertension. Biochemical screening showed plasma sodium of $109 \mathrm{mmol} / \mathrm{l}$, potassium $3.4 \mathrm{mmol} / \mathrm{l}$, osmolality 242 $\mathrm{mOsm} / \mathrm{kg}$, and AVP $1.0 \mathrm{pg} / \mathrm{ml}$. Plasma sodium concentration returned to normal within 2 weeks.

\section{Discussion}

Detectable quantities of plasma AVP were found in all 6 patients despite severe hypo-osmolality which should have completely suppressed AVP secretion. Non-osmolar AVP secretion is very common in normovolaemic and hypovolaemic types of hyponatraemia (Anderson et al., 1985). It is baroreceptor mediated, and contributory factors in diuretic-induced hyponatraemia include: (i) net sodium deficit accompanying extracellular fluid depletion; (ii) a shift of sodium from extracellular to intracellular fluid (Fuisz et al., 1962), and (iii) reduction in cellular volume secondary to loss of intracellular potassium (Fichman et al., 1971). Radioimmunoassay of plasma AVP has previously demonstrated measurable amounts in diuretic-induced hyponatraemia (Abramow \& Cogan, 1984).

The rapid rise in plasma sodium concentration in Case 1, which occurred after stopping the diuretic, was accompanied by a raised urine/plasma osmolal ratio, 
presumably reflecting circulating AVP activity. In the absence of a water diuresis, it is possible that the rise in plasma sodium concentration results from intense tubular sodium reabsorption associated with sodium deficiency. Balance studies have suggested that hyponatraemia in this phase may be due to (i) ADH-induced water conservation, and (ii) sodium deficiency (Fuisz et al., 1962). Experimental studies have confirmed that sodium deficiency is accompanied by anti-diuresis and a raised urine to plasma osmolal ratio, even when ADH is absent (Kleeman et al., 1957; Harrington, 1972).

Defective renal diluting ability is a feature of the early recovery phase of diuretic-induced hyponatraemia. Progressive improvement in the ability to excrete a water load occurs as recovery continues, which probably relates to improving sodium balance. Impaired water excretion is well recognized in sodiumdepleted patients (Schedl \& Bartter, 1960). Limitation of renal water excretion in hyponatraemia arises from decreased sodium delivery to the cortical diluting sites in the distal tubule, and increased angiotensin II

\section{References}

ABRAMOW, M. \& COGAN, E. (1984). Clinical aspects and patho-physiology of diuretic-induced hyponatraemia. In Advances in Nephrology From The Necker Hospital. p. 1. Year Book Medical Publishers: Chicago.

ANDERSON, R.J., CHUNG, H-M., KLUGE, R. \& SCHRIBER, R.W. (1985). Hyponatraemia: a prospective analysis of its epidemiology and the pathogenetic role of vasopressin. Annals of Internal Medicine, 102, 164.

FICHMAN, M.P., VORHERR, H., KLEEMAN, C.R. \& TELFER, N. (1971). Diuretic-induced hyponatraemia. Annals of Internal Medicine, 75, 853.

FUISZ, R.E., LANDERS, D.P. \& COHEN, P. (1962). Diureticinduced hyponatraemia and sustained anti-diuresis. American Journal of Medicine, 33, 783.

HARRINGTON, A.R. (1972). Hyponatraemia due to sodium depletion in the absence of vasopressin. American Journal of Physiology, 222, 768.

HOLLENBERG, N.K., WILLIAMS, G.H., BURGER, B., ICHIK- concentrations (Hollenberg et al., 1976). Normal water-load tests have been reported in diuretic-induced hyponatraemia (Fichman et al., 1971), but the precise time after stopping the diuretic was not stated. Figure 2 clearly illustrates sequential change in water load tests performed in the same individual throughout the recovery period. A random water load test in Case 3 on day 5 showed impairment of renal diluting ability, whereas in Case 5 on day 10 the test was normal.

The effects of thirst and polydipsia could not be gauged. Inappropriately increased water ingestion, however, in the presence of measurable circulating AVP and defective renal diluting ability, will inevitably exacerbate hyponatraemia due to water retention.

\section{Acknowledgements}

I am grateful to the Supra-Regional Assay Service for estimation of plasma AVP. I wish to thank Miss Julie E. Davies for secretarial assistance.
AWA, I. \& ADAMS, D.F. (1976). Blockade and stimulation of renal, adrenal and vascular angio-tensin II receptors, with 1-Sar, 8-Ala angiotensin II in normal man. Journal of Clinical Investigation, 57, 39.

KLEEMAN, C.R., MAXWELL, M.H. \& ROCKNEY, R. (1957). Production of hypotonic urine in humans in the probable absence of anti-diuretic hormone (ADH). Proceedings of the Society for Experimental Biology and Medicine, 96, 189.

ROBERTS, C.J.C., MITCHELL, J.V. \& DONLEY, A.J. (1977). Hyponatraemia: adverse effect of diuretic treatment. British Medical Journal, 1, 210.

SCHEDL, H.P. \& BARTTER, F.C. (1960). Explanation for and experimental correction of abnormal water diuresis in cirrhosis. Journal of Clinical Investigation, 39, 248.

STROMBERG, P., FORSLING, M.L. \& AKERLAUND, M. (1981). Effects of prostaglandin inhibition on vasopressin levels in women with primary dysmenorrhoea. Obstetrics and Gynaecology, 58, 206. 